\title{
THE FEATURES OF THE FUNCTIONAL STATE OF MUSCLE FIBERS IN PATIENTS WITH MULTIPLE SCLEROSIS WITH SPASTICITY ACCORDING TO THE RESULTS OF ELECTRONEUROMYOGRAPHY
}

DOMRES NATALIYA V., neurologist of the Department of demyelinating diseases of the nervous system of Kiev City Clinical Hospital № 4; doctoral student of the Department of neurology of A.A. Bogomolets National Medical University, Ukraine, 03110, Kiev, Solomenskaya str., 17, tel. +38-093-745-66-39, e-mail: nata003@ukr.net

\begin{abstract}
Aim. The aim of the study was to assess the functional state of muscle fibers in spasticity in patients with multiple sclerosis (MS) according to the results of electroneuromyography. Material and methods. The study of electroneuromyography indices was performed on 51 MS patients with spasticity (26 women and 25 men aged 24 to 71 , mean age $43,8 \pm 1,6)$. The study was conducted via application of a stimulation non-invasive technique using a Nihon Kohden apparatus (motor fibers of $\mathrm{n}$. medianus, n. tibialis, and sensory fibers of $n$. medianus, F-wave $n$. medianus, $n$. tibialis, and $\mathrm{H}$-reflex). Spasticity of the upper and lower extremities was assessed using the Modified Ashworth Scale. Results and discussion. Significant decrease in the amplitude of the M-response was revealed when examining both the upper and lower extremities in MS patients with minimal clinical signs of spasticity. Indicators of late electrophysiological phenomena (F-amplitude mean) changed only in the lower extremities, where the level of spasticity was higher. Threshold levels of the M-amplitude were identified in order to assess the risk of a high total score of spasticity $>12$. Conclusion. The results of the study revealed the main electrophysiological indicators of early manifestations of spasticity in MS patients. The main electrophysiological indicator of the early manifestations of spasticity in patients with multiple sclerosis is a decrease in the amplitude of M-response. The mean F-amplitude decreases according to the increase in spasticity in the lower extremities in patients with multiple sclerosis having different levels of spasticity. Key words: spasticity, multiple sclerosis, M-amplitude, electrophysiologic phenomena.

For reference: Domres NV. The features of the functional state of muscle fibers in patients with multiple sclerosis with spasticity according to the results of electroneuromyography. The Bulletin of Contemporary Clinical Medicine. 2020; 13 (5): 46-56. DOI: 10.20969/VSKM.2020.13(5).46-56.
\end{abstract}

\section{ОСОБЕННОСТИ ФУНКЦИОНАЛЬНОГО СОСТОЯНИЯ МЫШЕЧНЫХ ВОЛОКОН У БОЛЬНЫХ РАССЕЯННЫМ СКЛЕРОЗОМ СО СПАСТИЧНОСТЬЮ ПО РЕЗУЛЬТАТАМ ЭЛЕКТРОНЕЙРОМИОГРАФИИ}

\footnotetext{
ДОМРЕС НАТАЛЬЯ ВАДИМОВНА, врач-невропатолог отделения демиелинизирующих заболеваний нервной системы Киевской городской клиническаой больницы № 4; соискатель кафедры неврологии Национального медицинского университета им. А.А. Богомольца, Украина, 03110, Киев, ул. Соломенская, 17, тел. +38-093-745-66-39, e-mail: nata003@ukr.net
}

\begin{abstract}
Реферат. Цель исследования - провести оценку функционального состояния мышечных волокон при спастичности у больных рассеянным склерозом по результатам электронейромиографии. Материал и методы. Проведено исследование показателей электронейромиографии у 51 больного рассеянным склерозом со спастичностью [26 женщин и 25 мужчин в возрасте от 24 до 71 лет, средний возраст составил $(43,8 \pm 1,6)$ года]. Исследование проводилось по стимуляционной неинвазивной методике на аппарате Nihon Kohden (двигательные волокна $n$. medianus, $n$. tibialis, чувствительные волокна $n$. medianus, F-волна $n$. medianus, $n$. tibialis, $\mathrm{H}$-ресрлекс). Спастичность верхних и нижних конечностей оценивали по модифицированной шкале Ashworth. Результаты и их обсуждение. У пациентов с рассеянным склерозом с минимальными клиническими признаками спастичности выявлено достоверное снижение амплитуды М-ответа при исследовании как верхних, так и нижних конечностей. Показатели поздних электрофизиологических феноменов (F-амплитуда средняя) изменялись только на нижних конечностях, где уровень спастичности был выше. Были выявлены пороговые уровни М-амплитуды для оценки риска развития высокого суммарного балла спастичности $>12$. Выводы. Результаты исследования выявили основные электрофизиологические индикаторы ранних проявлений спастичности у больных РС. Основным электрофизиологическим индикатором ранних проявлений спастичности у больных рассеянным склерозом является снижение амплитуды М-ответа. F-амплитуда средняя снижается соответственно росту спастичности в нижних конечностях у пациентов с рассеянным склерозом разного уровня спастичности.

Ключевые слова: спастичность, рассеянный склероз, М-амплитуда, электрофизиологические феномены. Для ссылки: Домрес, Н.В. Особенности функционального состояния мышечных волокон у больных рассеянным склерозом со спастичностью по результатам электронейромиографии / Н.В. Домрес // Вестник современной клинической медицины. - 2020. - Т. 13, вып. 5. - С.46-56. DOI: 10.20969/VSKM.2020.13(5).46-56.
\end{abstract}

ntroduction. In contemporary neurology, the problem of early diagnostics and the development of multiple sclerosis (MS) is susceptible to the overpowering relevance and medical and social significance. According to $\mathrm{WHO}, \mathrm{MS}$ is the most frequent cause of young people being incapable for employment not related to trauma $[1,2]$. Spasticity is a typical symptom of multiple sclerosis (MS). According to a survey conducted by the North American Research Consortium on MS (NARCOMS, 2001), spasticity occurs in 60-85\% of MS patients [3, 4]. Increased muscle tone leads to limited participation in public life, primarily due to limited 
motor functions. These factors lead to decreased independence, impair quality of life and may affect the role that a person plays in the family [5]. Spastic paresis is one of the main reasons for disability in such patients. Spasticity affects the functions of the nervous system, which is reflected in the scale of functional systems (FS) and the level of disability on the extended scale of disability assessment (EDSS) [6, 7].

However, thorough examination of muscle tone and the degree of spasticity is not required during a routine examination by a neurologist, although the diagnosis of these disorders in the early stages of the disease can lead to timely treatment and improvement of quality of life. Electroneuromyography as a method to clarify the degree of damage and the extent of involvement in the pathological process of muscle tissue, is mainly used in medical practice for the differential diagnosis of MS.

Analysis of Studies on this Topic. Objective assessment of severity of spasticity is important. In addition to clinical examination, spasticity can be assessed on the basis of clinical scales, biomechanical and electrophysiological methods [3, 8]. Currently, the Modified Ashworth Scale is most commonly used to assess the severity of spasticity due to its ease of use and extensive assessment of the patient's muscle condition. This scale is time-tested and is widely used to assess the condition of a patient with spasticity and the effectiveness of treatment [7, 10, 11, 12, 13].

Electrophysiological examination (electroneuromyography) allows a detailed study of the functional state of muscle fibers and is an objective method of studying spasticity $[9,14]$.

Although MS is a disease of the central nervous system and it is believed that electrodiagnostic tests of the peripheral nervous system should not be abnormal, studies suggest that peripheral nerves may also be affected by MS [15]. The studies evaluated the late electrophysiological phenomena: the H-reflex, since an increase in the excitability of $\underline{\alpha}$-motor neurons is an important mechanism of spasticity $[12,16]$. An analysis of more than 185 sources showed that the following methods are most often used to assess spasticity: $\mathrm{H}$-reflex, T-reflex and extended reflex. Moreover, the correlation with other biomechanical or clinical indicator for assessing spasticity was moderate or weak [16]. Studies of the characteristics of the F-wave indicate early changes in the average amplitude of the F-wave (decrease) even before the development of spasticity [15]. The importance of early electrophysiological phenomena (amplitude and latency of the M-response) in the diagnosis of spasticity has not been receiving enough attention.

Objective: To assess the functional state of muscle fibers in spasticity in patients with MS by electroneuromyography.

Material and methods. We examined 51 patients with signs of spasticity who were being treated at the Kyiv City Center for Multiple Sclerosis. The age of the patients ranged from 24 to 71 years, the mean age was $43,8 \pm 1,6$. The patients were 26 women and 25 men. There were 15 patients with secondary-progressive course, 5 patients with primary-progressive course and 31 patients with recurrent-remitting course of the disease. The duration of the disease ranged from 1 to 33 years, on average 13,22 $\pm 0,84$.

The Modified Ashwort Scale was used to quantify the severity of changes in muscle tone. Tone was measured in extensor and flexor muscle groups, and scores ranged from 0 to 3 (maximum Ashworth score is 4, but no such patients were studied). The total spasticity score was calculated by adding the Ashworth scale of spasticity in 4 lower limb muscle groups (thigh, knee flexors, knee extensors, feet) and 2 upper limb muscle groups (shoulder and forearm flexors and extensors).

Electroneuromyography was performed using noninvasive stimulation technique with a Nihon Kohden device in the following areas:

- Motor fibers of $n$. medianus, $n$. tibialis.

- Sensory fibers of $m$. medianus.

- F-wave of $n$. medianus, $n$. tibialis.

- H-reflex.

- We evaluated the following findings:

- When examining motor and sensory fibers of $n$. medianus and $n$. tibialis: M-Response Amplitude, Latency, Interval, Velocity.

- When examining the F-wave of $n$. medianus, $n$. tibialis: M-Latency, M-Amplitude, F-Frequency, Average F-Latency, Average F-Amplitude.

-When examining the H-Reflex: M-Latency, Maximum $\mathrm{M}$, Maximum $\mathrm{H}, \mathrm{M} / \mathrm{H}$ Ratio, $\mathrm{H}$-Latency.

The primary database was created in Microsoft Excel 2019 MSO (16.0.13029.20342) (Microsoft Corporation, USA), and the statistical analysis was performed using Microsoft Excel 2019 and the Statistica 12,0 (StatSoft, Inc, USA). Statistical processing of the data was performed_using the methods of descriptive statistics: the mean value, standard error of the mean value $(\mathrm{M} \pm \mathrm{m})$ and the median value were calculated.

Significance assessment was performed according to the Mann-Whitney U-test for 2 groups of observations and using the Kruskal-Wallis test for 3 groups of patients. Analyzing the influence of factor traits, their prognostic characteristics were determined by calculating of odds ratio (OR - odds ratio) with $95 \%$ confidence interval and assessment of statistical significance of OR - results $(95 \% \mathrm{Cl})$.

Results and discussion. The level of spasticity in patients on the Ashworth scale ranged from 0,4 to 3 points. The average score of spasticity was $1,68 \pm 0,06$. The total score of spasticity in patients ranged from 4 to 24 points. Depending on the total score of spasticity, patients were divided into two groups with a total score of 4-12 points (28 patients) and 13-24 points (23 patients). Patients were also divided into 3 groups depending on the level of spasticity. The first group consisted of 18 patients with a mild level of spasticity $(0,4-1$ point $)$, the second of 24 patients with a medium level of spasticity (1,5-2 points), and the third group_of 9 patients with severe level of spasticity (2,1-3 points). In the three groups by average spasticity the EDSS level ranged from 3 to 7 points (Fig. 1). By duration of the disease, patients were distributed as follows: from 1 to 9 years -18 patients, from 10 to 20 years -24 patients, from 21 to 33 years -9 patients. 31 patients were diagnosed with RRMS, 15 patients with SPMS, and 5 with PPMS. 


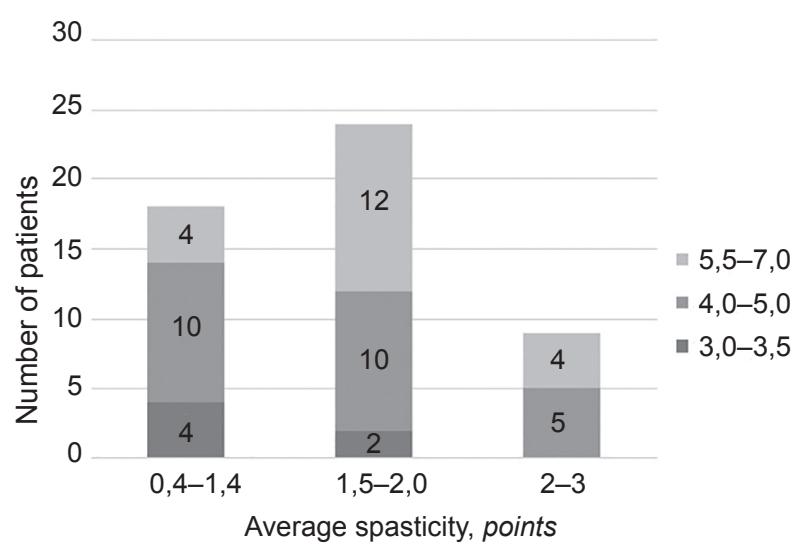

Fig. 1. Average spasticity in relation to EDSS level

Patients were divided into groups according to the level of spasticity on the Ashworth scale. Although the vast majority of patients did not have upper extremity spasticity [only 8 patients $(16 \%)$ had upper extremity spasticity], an electromyographic examination of the upper extremity was performed in all patients to assess the functional status of the muscle fibers. Patients with spasticity of the upper extremities $(n=8)$ had from 0 to $1+$ points on the Ashworth scale (mean score $0,86 \pm 0,12$ ). The functional state (M-response) of the muscles of the upper limb (motor fibers of $\mathrm{n}$. medianus) in patients with MS was assessed depending on the presence or absence of spasticity. No significant differences were found. There was a tendency of increased M-latency with stimulation of the hand $[(4,86 \pm 0,41) \mathrm{ms}]$ and elbow $[(11,03 \pm 0,37) \mathrm{ms}]$ in patients with spasticity, the amplitude of the M-response was lower in patients with spasticity in all points of stimulation: wrist $[(10,38 \pm 1,12) \mathrm{mV}]$, elbow $[(11,03 \pm 0,37) \mathrm{mV}]$, armpits $[(12,01 \pm 0,53) \mathrm{mV}]$.

The functional state (M-response) of the muscles of the upper extremity (motor fibers $n$. Medianus) in patients with MS was also assessed depending on the total score of spasticity (the first group - 4-12 points, the second group - 13-24 points) (Table 1). Recording of muscle M-response is the most common electrophysiological study of motor fibers. M-response is the total potential of muscle fibers that is registered from the muscle when the innervating nerve is stimulated by a single stimulus. The decrease in the amplitude of the M-response when stimulating the distal point occurs when axons are affected, during muscular processes (both primary and secondary). There was a significant difference between the findings in these groups. At stimulation of the elbow area $[(11,60 \pm 0,25) \mathrm{ms} ; p<0,01]$ and armpit $[(12,99 \pm 0,25) \mathrm{ms} ; p<0,05]$ in patients with a higher total score of spasticity there is an increase in M-latency, the amplitude of the M-response was lower in patients with a higher total score of spasticity at all points of stimulation: wrist $[(9,85 \pm 0,58) \mathrm{mV} ; p<0,03]$, elbow $[(4,27 \pm 0,42) \mathrm{mV})$; $p<0,01]$, and armpits $[(6,05 \pm 0,78) \mathrm{mV} ; p<0,01]$. It should be noted that a decrease in the amplitude of the $M$ response in patients with spasticity means a decrease in the number of muscle fibers involved in the generation of the M-response due to impaired conduction along the axons. A decrease in the amplitude of the M-response was registered in the absence of clinical manifestations of spasticity in the upper extremities and in the presence of spasticity in the lower extremities. Therefore, a decrease in the amplitude of the M-response is an early indicator of spasticity. Latency is a time delay from the moment of stimulation to the occurrence of the M-response when the nerve is stimulated at the distal point. As we know, the increase in latency is characteristic of demyelinating nerve damage.

We identified threshold levels of M-amplitude to assess the risk of developing a high spasticity score of $>12$ (Fig. 2).

Decreased level of M-amplitude on the wrist less than $9,85 \mathrm{mV}$ increased the risk of developing high



Fig. 2. Prognostic assessment of the risk of severe spasticity ( $>12$ points) with a decrease in M-amplitude below the threshold level

Assessment of the functional state (M-response) of the upper limb muscles (motor fibers of $n$. medianus) in patients with MS depending on the total spasticity score

\begin{tabular}{|l|c|c|c|c|}
\hline \multirow{2}{*}{ Indicator } & \multirow{2}{*}{ Total score } & \multicolumn{3}{|c|}{ Stimulation point } \\
\cline { 2 - 5 } & & Wrist & Elbow & Armpit \\
\hline \multirow{3}{*}{ M-Latency, $m s$} & $4-12$ & $4,73 \pm 0,34$ & $10,34 \pm 0,36$ & $1,52 \pm 0,34$ \\
\cline { 2 - 5 } & $13-24$ & $4,77 \pm 0,26$ & $11,60 \pm 0,25$ & 0,004 \\
\cline { 2 - 5 } & $p$ & $>0,05$ & 0,01 & $12,89 \pm 3,49$ \\
\hline \multirow{3}{*}{ M-Amplitude, $m V$} & $4-12$ & $11,19 \pm 0,57$ & $6,43 \pm 0,64$ & $6,05 \pm 0,78$ \\
\cline { 2 - 5 } & $13-24$ & $9,85 \pm 0,58$ & $4,27 \pm 0,42$ & 0,01 \\
\cline { 2 - 5 } & $p$ & 0,03 & 0,01 & $6,73 \pm 3,85$ \\
\hline \multirow{5}{*}{ Interval, $m s$} & $4-12$ & $4,98 \pm 0,32$ & $5,71 \pm 0,21$ & $1,45 \pm 0,17$ \\
\cline { 2 - 5 } & $13-24$ & $5,14 \pm 0,24$ & $6,53 \pm 0,16$ & $>0,05$ \\
\cline { 2 - 5 } & $p$ & $>0,05$ & 0,04 & $177,43 \pm 23,09$ \\
\hline \multirow{3}{*}{ Velocity, $m / s$} & $4-12$ & - & $53,43 \pm 2,83$ & $158,57 \pm 30,31$ \\
\cline { 2 - 5 } & $13-24$ & - & $46,01 \pm 1,08$ & $>0,05$ \\
\cline { 2 - 5 } & $p$ & - & 0,05 & \\
\hline
\end{tabular}

Foot-note: $p$ - confidence estimation based on the Mann - Whitney test. 
spasticity $>12$ points $[\mathrm{OR}(95 \% \mathrm{Cl})=4,30(1,84-10,07)$; $p=0,001]$. Decreased level of $\mathrm{M}$-amplitude in the armpits to less than $6,05 \mathrm{mV}$ also significantly increased the chances of developing spasticity $>12$ points [OR $(95 \%$ Cl) $=4,02(1,60-10,09) ; p=0,001]$.

We also evaluated late electrophysiological phenomena: F-wave and H-reflex depending on the presence and absence of spasticity.

According to current data, $\mathrm{F}$-wave is motor response of the muscle, which occurs periodically during supramaximal stimulation, and in its physiological essence is a muscular response to reverse discharge, which occurs as a result of antidromic excitation of the motoneuron. Thus, the parameters of the F-wave characterize the changes in the functional state of the spinal cord motoneurons depending on the degree of spinal and supraspinal exposure.

We identified significant changes in F-wave latency during stimulation of the n.medianus (Table 2).

$\mathrm{F}$-wave latency in $\mathrm{n}$. medianus decreased in patients with clinical signs of spasticity of the upper extremities to $(2,17 \pm 0,72) \mathrm{ms} ; p=0,01$. While the average F-latency increased in patients with spasticity to $(62,48 \pm 31,51) \mathrm{ms}$; $p=0,04$. No significant changes in F-amplitude were identified.

The M-response of the muscles of the lower extremity (motor fibers of $n$. tibialis) was evaluated in patients with MS depending on the total score of spasticity, as well as in groups with different mean levels of spasticity.
There was a significant decrease in the amplitude of M-response at the point of stimulation of the ankle in a group of patients with a higher total spasticity score from $(13,73 \pm 1,21) \mathrm{mV}(4-12$ points) to $8,68 \pm 1,06$ (13-24 points) $(p=0,003)$ and knees from $25,21 \pm 14,49$ (4-12 points) to $3,17 \pm 0,80(13-24$ points) $(p=0,03)$. Differences in latency were statistically insignificant (Table 3). Therefore, the M-amplitude is the most sensitive indicator of subclinical manifestations of spasticity.

At the same time, when studying the latency of motor fibers of $n$. tibialis in three groups of patients with different average levels of spasticity we found a significant difference between this indicator in groups of patients and its reduction at the ankle point from $7,78 \pm 0,34$ to $6,95 \pm 0,47(p=0,018)$, which is not typical for demyelinating lesions of nerve fibers (Table 4).

With increasing spasticity, the amplitude of the M-response decreased in proportion to the amount of spasticity from $15,12 \pm 1,67$ (group $0,4-1$ points) to $5,90 \pm 1,20$ (group $2,1-3$ points) $(p=0,01)$. Therefore, in patients with severe spasticity, the amplitude of the M-response is the lowest.

When assessing the late electrophysiological phenomenon ( $F$-wave) during stimulation of the muscles of the lower extremity (n. tibialis), we found that the average F-latency significantly increased $(p=0,007)$ with increasing levels of spasticity in patients (Table 5). Thus, in the group of patients with the lowest level of spasticity $(0,4-1$ points) the average F-latency was

Ta ble 2

Assessment of the functional state (F-wave) of the muscles of the upper extremity $n$. medianus in MS patients depending on the presence of spasticity in the upper extremity

\begin{tabular}{|c|c|c|c|}
\hline Indicator & $\begin{array}{l}\text { Presence }(+) \text { or absence }(-) \\
\text { of spasticity }\end{array}$ & F-wave of $n$. medianus & $p$ \\
\hline \multirow{2}{*}{ Latency, $m s$} & + & $2,17 \pm 0,72$ & \multirow[b]{2}{*}{0,01} \\
\hline & - & $4,60 \pm 0,30$ & \\
\hline \multirow{2}{*}{ Amplitude, $m V$} & + & $7,58 \pm 1,74$ & \multirow[b]{2}{*}{$>0,05$} \\
\hline & - & $8,17 \pm 0,62$ & \\
\hline \multirow{2}{*}{ F-frequency, $\mathrm{Hz}$} & + & $61,11 \pm 4,84$ & \multirow[b]{2}{*}{$>0,05$} \\
\hline & - & $49,00 \pm 3,37$ & \\
\hline \multirow{2}{*}{ Average F-latency, $m s$} & + & $62,48 \pm 31,51$ & \multirow[b]{2}{*}{0,04} \\
\hline & - & $29,77 \pm 0,59$ & \\
\hline \multirow{2}{*}{ Average F-amplitude, $m V$} & + & $632,78 \pm 98,67$ & \multirow[b]{2}{*}{$>0,05$} \\
\hline & - & $567,79 \pm 71,10$ & \\
\hline
\end{tabular}

Foot-note: $p$ - confidence estimation based on the Mann - Whitney test.

Ta ble 3

Assessment of the functional state of the muscles (M-response) of the lower extremity (motor fibers of $n$. tibialis) in MS patients depending on the total score of spasticity

\begin{tabular}{|l|c|c|c|c|}
\hline \multirow{2}{*}{ Indicator } & \multirow{2}{*}{ Stimulation point } & \multicolumn{3}{|c|}{ Total spasticity score } \\
\cline { 2 - 5 } & & $4-12$ & $13-24$ & $p$ \\
\hline \multirow{2}{*}{ M-Latency, $m s$} & Ankle & $7,29 \pm 0,27$ & $7,24 \pm 0,33$ & $>0,05$ \\
\cline { 2 - 5 } & Knee & $16,75 \pm 0,47$ & $17,21 \pm 0,63$ & $>0,05$ \\
\hline \multirow{2}{*}{ M-Amplitude, $m V$} & Ankle & $13,73 \pm 1,21$ & $8,68 \pm 1,06$ & 0,003 \\
\cline { 2 - 5 } & Knee & $25,21 \pm 14,49$ & $3,17 \pm 0,80$ & 0,03 \\
\cline { 2 - 5 } Interval & Ankle & $7,29 \pm 0,26$ & $7,56 \pm 0,28$ & $>0,05$ \\
\cline { 2 - 5 } & Knee & $11,44 \pm 1,34$ & $10,08 \pm 0,41$ & $>0,05$ \\
\hline \multirow{2}{*}{ Velocity, $m / s$} & Ankle & - & - & 0,05 \\
\cline { 2 - 5 } & Knee & $50,49 \pm 2,60$ & $46,30 \pm 3,36$ & 0,05 \\
\hline
\end{tabular}

Foot-note: $p$ - confidence estimation based on the Mann - Whitney test. 
$(52,93 \pm 1,15) \mathrm{ms}$, and in the group with the highest level of spasticity $(2,3-3$ points $)-(58,48 \pm 0,91) \mathrm{ms}$. $F$, the average amplitude depending on the level of spasticity, respectively, decreased from $(621,27 \pm 118,62) \mathrm{mV}$ to $(476,12 \pm 119,67) \mathrm{mV}(p=0,008)$.

We also studied the H-reflex, which is associated with a descending inhibitory effect of the brain on the spinal cord. But the difference in the groups of patients was insignificant (Table 6).

To sum up the results of our study, we note once again that multiple sclerosis patients with different levels of spasticity showed a significant decrease in the amplitude of the M-response in the study of both upper and lower extremities, which means a decrease in the number of muscle fibers involved in M-responses due to violation of the conduction of the axons. This is the most sensitive indicator of early manifestations of spasticity. While indicators of late electrophysiological phenomena (F-wave), especially average F-amplitude, vary in patients with spasticity only on the lower extremities.
Conclusion. As a result of the clinical and electrophysiological study of patients with MS, one of the urgent problems of neurology, determination of indicators of early signs of spasticity, which is one of the main disabling factors in patients with MS, was further developed. The obtained results are of practical importance, due to the fact that early diagnosis of spasticity in MS allows a decision to be made on the timely appointment of symptomatic therapy and delay the development of disability.

Based on the results of the study, the following conclusions were made:

1. The results of electroneuromyographic examination showed that the main electrophysiological indicator of early manifestations of muscle spasticity of the upper and lower extremities in patients with multiple sclerosis is a decrease in the amplitude of the M-response.

2. Late electrophysiological phenomenon - average F-amplitude decreases with increase of spasticity

Table 4

Assessment of the functional state (M-response) of the muscles of the lower extremity (motor fibers of $n$. tibialis) in patients with MS depending on the level of spasticity.

\begin{tabular}{|c|c|c|c|c|c|}
\hline \multirow{2}{*}{ Indicator } & \multirow{2}{*}{ Stimulation point } & \multicolumn{3}{|c|}{ Spasticity level } & \multirow{2}{*}{$p$} \\
\hline & & $0,4-1$ & $1,5-2$ & $2,1-3$ & \\
\hline \multirow{2}{*}{ Latency, ms } & Ankle & $7,78 \pm 0,34$ & $7,05 \pm 0,32$ & $6,95 \pm 0,47$ & 0,018 \\
\hline & Knee & $17,74 \pm 0,64$ & $16,10 \pm, 55$ & $17,69 \pm 0,44$ & $>0,05$ \\
\hline \multirow{2}{*}{ Amplitude, $m V$} & Ankle & $15,12 \pm 1,67$ & $10,13 \pm 1,11$ & $5,90 \pm 1,20$ & 0,01 \\
\hline & Knee & $20,64 \pm 16,30$ & $16,11 \pm 12,70$ & $4,63 \pm 1,31$ & $>0,05$ \\
\hline \multirow{2}{*}{ Interval } & Ankle & $7,81 \pm 0,34$ & $7,21 \pm 0,29$ & $7,30 \pm 0,39$ & $>0,05$ \\
\hline & Knee & $11,58 \pm 1,51$ & $10,48 \pm 1,19$ & $10,44 \pm 0,57$ & $>0,05$ \\
\hline \multirow{2}{*}{ Velocity, $\mathrm{m} / \mathrm{s}$} & Ankle & - & - & - & $>0,05$ \\
\hline & Knee & $48,26 \pm 3,92$ & $50,25 \pm 2,89$ & $44,36 \pm 2,17$ & $>0,05$ \\
\hline
\end{tabular}

Foot-note: $p$ - confidence estimation based on the Kruskal - Wallis test.

T a ble 5

Assessment of the functional state of the muscles of the lower extremity (F-wave of $n$. tibialis) in patients with MS depending on the level of spasticity

\begin{tabular}{|l|c|c|c|}
\hline \multirow{2}{*}{ Indicator } & \multicolumn{2}{c|}{ Spasticity level } & \multicolumn{2}{c|}{$p$} \\
\cline { 2 - 4 } & $0,4-1$ & $1,5-2$ & $2,1-3$ \\
\hline M-Latency, $m s$ & $4,4 \pm 0,52$ & $5,19 \pm 0,36$ & $6,18 \pm 0,83$ \\
\hline M-Amplitude, $m V$ & $3,92 \pm 0,81$ & $6,78 \pm 1,09$ & $8,56 \pm 0,95$ \\
\hline F-Frequency, $H z$ & $78,85 \pm 4,72$ & $65,53 \pm 4,80$ & $74,62 \pm 8,82$ \\
\hline Average F-Latency, $m s$ & $52,93 \pm 1,15$ & $53,38 \pm 1,14$ & 58,05 \\
\hline Average F-Amplitude, $m V$ & $621,27 \pm 118,62$ & $487,97 \pm 79,44$ & $476,12 \pm 119,67$ \\
\hline
\end{tabular}

Foot-note: $p$ - confidence estimation based on the Kruskal - Wallis test.

Assessment of the functional state of the muscles of the lower extremity (H-reflex) in MS patients depending on the presence of spasticity.

\begin{tabular}{|c|c|c|c|c|}
\hline Indicator & $0,4-1$ & $1,5-2$ & $2,1-3$ & $p$ \\
\hline M-Latency, $m s$ & $9,93 \pm 2,87$ & $8,28 \pm 1,12$ & $5,93 \pm 0,16$ & $>0,05$ \\
\hline Maximum M & $3,09 \pm 1,49$ & $3,02 \pm 0,67$ & $2,68 \pm 1,01$ & $>0,05$ \\
\hline Maximum $\mathrm{H}$ & $0,63 \pm 0,40$ & $1,27 \pm 0,63$ & $2,5 \pm 0,11$ & $>0,05$ \\
\hline M/H Ratio & - & $147,26 \pm 73,63$ & $44,3 \pm 0$ & $>0,05$ \\
\hline H-Latency, $m V$ & $31 \pm 0$ & $38,2 \pm 0$ & $29,77 \pm 1,93$ & $>0,05$ \\
\hline
\end{tabular}

Foot-note: $p$ - confidence estimation based on the Kruskal - Wallis test. 
increases in the lower extremities in multiple sclerosis patients experiencing different levels of spasticity.

3. Latency rates can both increase and decrease in patients with different levels of spasticity.

Transparency of the study. The study did not have sponsorship. The authors are solely responsible for the provision of the final version of the manuscript for publication.
Declaration of financial or other relationships. All authors participated in the conception and design of the study and in the writing of the manuscript. The final version of the manuscript was approved by all the authors. The authors did not receive a fee for the study.

\section{ОСОБЕННОСТИ ФУНКЦИОНАЛЬНОГО СОСТОЯНИЯ МЫШЕЧНЫХ ВОЛОКОН У БОЛЬНЫХ РАССЕЯННЫМ СКЛЕРОЗОМ СО СПАСТИЧНОСТЬЮ ПО РЕЗУЛЬТАТАМ ЭЛЕКТРОНЕЙРОМИОГРАФИИ}

\section{(перевод)}

$\mathrm{B}$ ведение. В современной неврологии проблема ранней диагностики и лечения рассеяного склероза (РС) отличается чрезвычайной актуальностью и медико-социальной значимостью. По данным ВО3, заболевание не связано с травмой, но является причиной нетрудоспособности молодых людей [1, 2].

Спастичность - типичный симптом рассеянного склероза. По результатам опроса Североамериканского исследовательского консорциума по реестру PC (NARCOMS, 2001), спастичность встречается у 60-85\% больных PC [3, 4]. Повышение тонуса мышц приводит к ограничению участия в общественной жизни, прежде всего, из-за ограничений двигательных функций. Эти факторы приводят к снижению уровня независимости, ухудшают качество жизни и могут влиять на роль, которую человек выполняет в семье [5]. Спастический парез - одна из главных причин инвалидизации таких больных. Спастичность влияет на функции нервной системы, что отражается в шкале функциональных систем (FS) и уровне инвалидизации по расширенной шкале оценки инвалидности (EDSS) [6, 7].

Вместе с тем тщательное обследование тонуса мышц и определение степени спастичности не является обязательным при рутинном осмотре больного неврологом, хотя диагностика этих расстройств на ранних этапах заболевания может способствовать своевременному лечению и улучшению качества жизни.

Электронейромиография как метод позволяет уточнить степень поражения и объем патологического процесса мышечной ткани, преимущественно применяется в лечебной практике для диффреренциальной диагностики РС.

Анализ исследований по данной теме. Большое значение имеет объективная оценка выраженности спастичности. В дополнение к клиническому обследованию спастичность можно оценить на основе клинических шкал, биомеханических и электрофизиологических методов [8, 9]. Сейчас для оценки выраженности спастичности чаще всего используется Модифицированная шкала Эшворта благодаря легкости применения и оценке состояния мышц больного. Данная шкала проверена временем и широко применяется для оценки состояния больного со спастичностью и для эфффективности лечения [7, 10, 11, 12, 13].

Электрофизиологическое исследование (электронейромиография) позволяет детально исследовать функциональное состояние мышечных волокон и является объективным методом исследования спастичности при различных заболеваниях [9, 14].

Хотя РС является заболеванием центральной нервной системы, и считается, что электродиагностические тесты периферической нервной системы не должны иметь отклонений от нормы, исследования показывают, что периферические нервы могут также страдать при РС [15]. В исследованиях оценивались поздние электрофизиологические феномены: Н-рефлекс, поскольку повышение возбудимости а-мотонейронов является важным механизмом спастичности $[12,16]$. Анализ более чем 185 источников показал, что для оценки спастичности чаще всего используются следующие методы: Н-рефрлекс, Т-рефрлекс и растянутый рефлекс. Причем корреляция с другими биомеханическими или клиническими параметрами оценки спастичности была умеренной или слабой [16]. Исследования характеристик F-волны указывают на ранние изменения средней амплитуды F-волны (снижение) еще до развития спастичности [15]. Значению ранних электрофизиологических феноменов (амплитуда и латентность М-ответа) в диагностике спастичности не уделялось достаточно внимания.

Цель работы - провести оценку функционального состояния мышечных волокон при спастичности у больных РС по результатам электронейромиографии.

Материал и методы. Был обследован 51 больной с признаками спастичности, проходивший лечение в Киевском городском центре рассеянного склероза. Возраст больных составлял от 24 до 71 лет, средний возраст - $(43,8 \pm 1,6)$ года. Среди пациентов было 26 женщин и 25 мужчин. Среди пациентов было 15 больных со вторично-прогрессирующим течением, 5 больных - с первично-прогрессирующим типом течения и 31 больной - с рецидивирующе-ремитирующим течением. Длительность заболевания составляла от 1 до 33 лет, в среднем $(13,22 \pm 0,84)$ года. 
Для количественной оценки выраженности изменений мышечного тонуса применяли модифицированную шкалу Эшворта (Modified Ashwort Scale). Тонус измеряли в группах мышц экстензоров и фрлексоров, оценку указывали в баллах от 0 до 3 (максимальный балл по шкале Эшворт - 4, но в исследовании таких больных не было). Суммарный балл спастичности вычисляли путем сложения баллов спастичности по шкале Ashworth в 4 группах мышц нижних конечностей (бедро, сгибатели колена, разгибатели колена, стопы) и 2 группах мышц верхних конечностей (сгибатели и разгибатели плеча и предплечья).

Электронейромиография проводилась по стимуляционной неинвазивной методике на аппарате Nihon Kohden на следующих участках:

- двигательные волокна n. medianus, n. tibialis;

- чувствительные волокна m. medianus;

- F-волна n. medianus, n. tibialis;

- Н-ресрлекс.

Оценивались следующие показатели:

- При обследовании двигательных и чувствительных волокон $n$. medianus, $n$. tibialis - амплитуда М-ответа, латентность, интервал, скорость проведения.

- При исследовании F-волны n. medianus, n. tibialis - М-латентность, M-амплитуда, F-частота, F-латентность средняя, F-амплитуда средняя.

- При исследовании Н-рефрлекса-М-латентность, максимум $\mathrm{M}$, максимум $\mathrm{H}$, соотношение $\mathrm{M} / \mathrm{H}, \mathrm{H}$-латентность.

Статистическая обработка данных проводилась по методам описательной статистики: вычислялось среднее значение и стандартная ошибка среднего значения $(\mathrm{M} \pm \mathrm{m})$. Оценка достоверности проводилась по U-критерию Манна - Уитни для двух групп и по критерию Краскела - Уоллиса для трех групп пациентов.

Анализируя влияние фракторных признаков отдельных величин, определяли их прогностические характеристики по показателям отношения шансов (OR - odds ratio) с 95\% доверительным интервалом и оценкой статистической значимости результатов OR (95\% ДI).

Статистическая оброботка полученных данных проводили с использованием программного пакета Statistica 12,0 («StatSoft, Inc», США) и Microsoft Office Профи Плюс 2019 ® Excel 2007, 13029.20344 («Microsoft Corporation», США).

Результаты и их обсуждение. Уровень спастичности у больных по шкале Эшворта был от 0,4 до 3 баллов. Средний балл спастичности составлял $1,68 \pm 0,06$. Суммарный балл спастичности у пациентов составлял от 4 до 24 баллов. В зависимости от суммарного балла спастичности пациенты были разделены на две группы: с суммарным баллом 4-12 и 13-24 балла. Также пациенты были разделены на 3 группы в зависимости от уровня спастичности. Первую группу составляли пациенты с легким уровнем спастичности (0,4-1 балл) - 18 больных, вторую - со средним уровнем спастичности $(1,5-$ 2 балла) - 24 больных, третью - с тяжелым уровнем спастичности (2,1-3 балла) - 9 больных. В трех группах разного уровня спастичности уровень EDSS был от 3 до 7 баллов (рис. 1). По длительности заболевания пациенты были разделены следующим образом: от 1 до 9 лет - 18 пациентов, от 10 до 20 лет - 24 пациента, от 21 до 33 лет - 9 пациентов.

Пациентов распределили на группы в зависимости от уровня спастичности по шкале Эшворта. Хотя у большинства пациентов не было спастичности верхних конечностей [лишь у 8 (16\%) больных была выявлена спастичность верхних конечностей], электронейромиографическое исследование верхней конечности проводились всем больным для оценки функционального состояния мышечных волокон. Пациенты со спастичностью верхних конечностей $(n=8)$ имели от 0 до 1+ балла по шкале

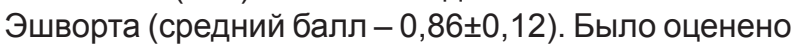
функциональное состояние (М-ответ) мышц верхней конечности (двигательные волокна $n$. medianus) у пациентов с РС в зависимости от наличия или отсутствия спастичности. Достоверно значимых различий не выявлено. Наблюдалась тенденция к увеличению М-латентности при стимуляции зоны кисти $[(4,86 \pm 0,41)$ мс] и локтя $[(11,03 \pm 0,37)$ мс] у пациентов со спастичностью, амплитуда М-ответа была ниже у пациентов со спастичностью во всех


локоть $(11,03 \pm 0,37)$ м], подмышки $[(12,01 \pm 0,53)$ мB].

Функциональное состояние (М-ответ) мышц верхней конечности (двигательные волокна $n$. medianus) у пациентов с РС было также оценено в зависимости от суммарного балла спастичности (первая группа - 4-12 баллов, вторая группа - 13-24 балла) (табл. 1, рис. 2). Регистрация М-ответа с мышц является наиболее распространенным электрофизиологическим исследованием двигательных волокон. М-ответ - суммарный потенциал мышечных волокон, регистрируется с мышцы при стимуляции иннервирующего нерва единичным стимулом. Снижение амплитуды М-ответа при стимуляции дистальной точки происходит при поражении аксонов, при мышечных процессах (как первичных, так и вторичных). Наблюдалась достоверная разница показателей в приведенных группах. При стимуляции зоны локтя $[(11,60 \pm 0,25)$ мс; $p<0,01]$ и подмышки $[(12,99 \pm 0,25)$ мс; $p<0,05]$ у пациентов с большим суммарным баллом спастичности имеется увели-



Рис.1. Соотношение средней спастичности и уровня EDSS 
Таблица 1

Оценка функционального состояния (М-ответ) мышц верхней конечности (двигательные волокна $n$. medianus) у пациентов с РС в зависимости от суммарного балла спастичности

\begin{tabular}{|c|c|c|c|c|}
\hline \multirow{2}{*}{ Показатель } & \multirow{2}{*}{$\begin{array}{c}\text { Суммарный } \\
\text { балл }\end{array}$} & \multicolumn{3}{|c|}{ Точка стимуляции } \\
\hline & & Запястье & Локоть & Подмышка \\
\hline \multirow{3}{*}{ М-латентность, мс } & $4-12$ & $4,73 \pm 0,34$ & $10,34 \pm 0,36$ & $11,52 \pm 0,34$ \\
\hline & $13-24$ & $4,77 \pm 0,26$ & $11,60 \pm 0,25$ & $12,99 \pm 0,55$ \\
\hline & $p$ & $>0,05$ & 0,01 & 0,004 \\
\hline \multirow{3}{*}{ М-амплитуда, мВ } & $4-12$ & $11,19 \pm 0,57$ & $6,43 \pm 0,64$ & $12,89 \pm 3,49$ \\
\hline & $13-24$ & $9,85 \pm 0,58$ & $4,27 \pm 0,42$ & $6,05 \pm 0,78$ \\
\hline & $p$ & 0,03 & 0,01 & 0,01 \\
\hline \multirow{3}{*}{ Интервал, мс } & $4-12$ & $4,98 \pm 0,32$ & $5,71 \pm 0,21$ & $6,73 \pm 3,85$ \\
\hline & $13-24$ & $5,14 \pm 0,24$ & $6,53 \pm 0,16$ & $1,45 \pm 0,17$ \\
\hline & $p$ & $>0,05$ & 0,04 & $>0,05$ \\
\hline \multirow{3}{*}{ Скорость, м/с } & $4-12$ & - & $53,43 \pm 2,83$ & $177,43 \pm 23,09$ \\
\hline & $13-24$ & - & $46,01 \pm 1,08$ & $158,57 \pm 30,31$ \\
\hline & $p$ & - & 0,05 & $>0,05$ \\
\hline
\end{tabular}

Примечание: $p$ - оценка достоверности по критерию Манна - Уитни.



Рис. 2. Прогностическая оценка риска развития выраженной спастичности (>12 баллов) при снижении М-амплитуды ниже порогового уровня

чение М-латентности, амплитуда М-ответа была ниже у пациентов с большим суммарным баллом спастичности во всех точках стимуляции - запястье $[(9,85 \pm 0,58)$ мВ; $p<0,03]$, локтя $[(4,27 \pm 0,42) \mathrm{MB}$; $p<0,01]$, подмышки $[(6,05 \pm 0,78)$ мВ; $p<0,01]$. Следует отметить, что снижение амплитуды М-ответа у пациентов со спастичностью означает уменьшение числа мышечных волокон, участвующих в генерации М-ответа в результате нарушения проведения по части аксонов. Снижение амплитуды М-ответа было зарегистрировано при отсутствии у пациентов клинических проявлений спастичности в верхних конечностях и при наличии спастичности в нижних конечностях. Следовательно, снижение амплитуды М-ответа является ранним индикатором развития спастичности. Латентность - временная задержка от момента стимуляции к возникновению М-ответа при стимуляции нерва в дистальной точке. Известно, что увеличение латентности характерно для демиелинизирующего поражения нерва.

По данным ROC-анализа были выявлены пороговые уровни М-амплитуды для оценки риска развития суммарного балла спастичности > 12. Снижение уровня М-амплитуды на запястье до менее чем 9,85 мВ повышало риск отношения шансов развития высокого уровня спастичности > 12 баллов [OR (95\% ДИ $)=4,30(1,84-10,07)](p=0,001)$. Снижение уровня М-амплитуды в подмышках до менее чем 6,05 мВ также достоверно повышало риск отношения шан- сов развития спастичности > 12 баллов [OR (95\% ДИ) $=4,02(1,60-10,09)](p=0,001)$.

Также оценивали поздние электрофизиологические феномены: F-волну и H-рефлекс в зависимости от наличия или отсутствия спастичности.

Согласно современным данным, F-волна представляет собой двигательный ответ мышцы, который возникает периодически при супрамаксимальной стимуляции и по своей фризиологической сути является мышечным ответом на обратной разряд, который возникает в результате антидромного возбуждения мотонейрона. Таким образом, параметры F-волны характеризуют изменения функционального состояния мотонейронов спинного мозга в зависимости от степени спинального и супраспинального воздействий.

Обнаружили достоверные изменения латентности F-волны при стимуляции n. medianus (табл. 2).

Латентность F-волны $n$. medianus снижалась у больных с клиническими признаками спастичности верхних конечностей до $(2,17 \pm 0,72)$ мс; $p=0,01$. В то время как F-латентность средняя увеличивалась у больных со спастичностью до $(62,48 \pm 31,510)$ мс; $p=0,04$, достоверных изменений F-амплитуды зарегистрировано не было.

Был оценен М-ответ мышц нижней конечности (двигательные волокна $n$. tibialis) у пациентов с PC в зависимости от суммарного балла спастичности, а также в группах с различным средним уровнем спастичности (табл. 3).

Зарегистрировано достоверное уменьшение амплитуды М-ответа в точке стимуляции щиколотки в группе пациентов с большим суммарным баллом спастичности с $(13,73 \pm 1,21)$ мВ (4-12 баллов) до $(8,68 \pm 1,06)$ мВ $(13-24$ балла) $(p=0,003)$ и

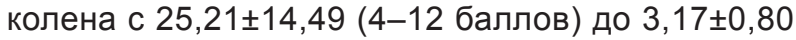
(13-24 балла) $(p=0,03)$. Различия показателя латентности оказались статистически недостоверными. То есть М-амплитуда является самым чувствительным показателем субклинических проявлений спастичности. 
В то же время при исследовании латентности двигательных волокон $n$. tibialis в трех группах пациентов с различным средним уровнем спастичности обнаружили достоверную разницу данного показателя в группах пациентов и его уменьшение в точке

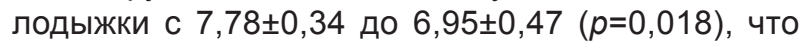
нехарактерно для демиелинизирующего поражения нервных волокон (табл. 4).

С ростом спастичности амплитуда М-ответа снижалась пропорционально величине спастично-


(группа 2,1-3 балла) ( $p=0,01)$. То есть у пациентов с выраженной спастичностью показатель амплитуды М-ответа низкий.

При оценке позднего электрофизиологического френомена (F-волна) при стимуляции мышц нижней конечности (n. tibialis) выявлено, что F-латентность средняя достоверно увеличивалась $(p=0,007)$ при росте уровня спастичности у пациентов (табл. 5). Так, в группе пациентов с низким уровнем спастичности (0,4-1 балла) F-латентность средняя имела значение $(52,93 \pm 1,15)$ мс, а в группе с высоким уровнем спастичности (2,3-3 балла) $(58,48 \pm 0,91)$ мс. F-амплитуда средняя зависимости от уровня спастичности соответственно уменьшалась с $(621,27 \pm 118,62)$ мВ до $(476,12 \pm 119,67)$ мВ $(p=0,008)$.

Исследовали Н-рефлекс, связанный с нисходящим тормозным влиянием головного мозга на спинной. Но разница показателей в группах больных была недостоверной (табл. 6).

Таблица 2

Оценка функционального состояния (F-волна) мышц верхней конечности $n$. medianus у пациентов c PC В зависимости от наличия спастичности в верхней конечности

\begin{tabular}{|l|c|c|c|}
\hline \multirow{2}{*}{ Показатель } & $\begin{array}{c}\text { Наличие (+) или } \\
\text { отсутствие (-) спастичности }\end{array}$ & F-волна $n$. medianus \\
\hline \multirow{3}{*}{ Латентность, $M C$} & + & $2,17 \pm 0,72$ & \multirow{2}{*}{0,01} \\
\hline \multirow{3}{*}{ Амплитуда, $M B$} & - & $4,60 \pm 0,30$ & \multirow{2}{*}{$>0,05$} \\
\hline \multirow{3}{*}{ F-частота, Гц } & + & $7,58 \pm 1,74$ & \multirow{2}{*}{$>0,05$} \\
\hline \multirow{2}{*}{ F-латентность средняя, $M C$} & - & $6,17 \pm 0,62$ & \multirow{2}{*}{0,04} \\
\hline \multirow{2}{*}{ F-амплитуда средняя, $M B$} & + & $41,11 \pm 4,84$ & \multirow{2}{*}{$>0,05$} \\
\cline { 2 - 3 } & + & $62,48 \pm 31,51$ & \\
\hline
\end{tabular}

Примечание: $p$ - оценка достоверности по критерию Манна - Уитни.

Та блица 3

Оценка функционального состояния мышц (М-ответ) нижней конечности (двигательные волокна n. tibialis) у пациентов с РС в зависимости от суммарного балла спастичности

\begin{tabular}{|c|c|c|c|c|}
\hline \multirow{2}{*}{ Показатель } & \multirow{2}{*}{ Точка стимуляции } & \multicolumn{2}{|c|}{ Суммарный балл спастичности } & \multirow[b]{2}{*}{$p$} \\
\hline & & $4-12$ & $13-24$ & \\
\hline \multirow{2}{*}{ М-латентность, мс } & Щиколотка & $7,29 \pm 0,27$ & $7,24 \pm 0,33$ & $>0,05$ \\
\hline & Колено & $16,75 \pm 0,47$ & $17,21 \pm 0,63$ & $>0,05$ \\
\hline \multirow{2}{*}{ М-амплитуда, мB } & Щиколотка & $13,73 \pm 1,21$ & $8,68 \pm 1,06$ & 0,003 \\
\hline & Колено & $25,21 \pm 14,49$ & $3,17 \pm 0,80$ & 0,03 \\
\hline \multirow{2}{*}{ Интервал } & Щиколотка & $7,29 \pm 0,26$ & $7,56 \pm 0,28$ & $>0,05$ \\
\hline & Колено & $11,44 \pm 1,34$ & $10,08 \pm 0,41$ & $>0,05$ \\
\hline \multirow{2}{*}{ Скорость, м/с } & Щиколотка & - & - & $>0,05$ \\
\hline & Колено & $50,49 \pm 2,60$ & $46,30 \pm 3,36$ & 0,05 \\
\hline
\end{tabular}

Примечание: $p$ - оценка достоверности по показателю Манна - Уитни.

Т аблица 4

Оценка функционального состояния (М-ответ) мышц нижней конечности (двигательные волокна $n$. tibialis) у пациентов с РС в зависимости от уровня спастичности

\begin{tabular}{|l|l|c|c|c|c|}
\hline \multirow{2}{*}{ Показатель } & \multirow{2}{*}{ Точка стимуляции } & \multicolumn{3}{|c|}{ Уровень спастичности } & \multirow{2}{*}{$p$} \\
\cline { 2 - 5 } & & $0,4-1$ & $1,5-2$ & $2,1-3$ & 0,018 \\
\hline \multirow{2}{*}{ Латентность, мс } & Щиколотка & $7,78 \pm 0,34$ & $7,05 \pm 0,32$ & $6,95 \pm 0,47$ & $>0,05$ \\
\cline { 2 - 6 } & Колено & $17,74 \pm 0,64$ & $16,10 \pm, 55$ & $17,69 \pm 0,44$ & 0,01 \\
\hline \multirow{2}{*}{ Амплитуда, мB } & Щиколотка & $15,12 \pm 1,67$ & $10,13 \pm 1,11$ & $5,90 \pm 1,20$ & $>0,05$ \\
\cline { 2 - 6 } & Колено & $20,64 \pm 16,30$ & $16,11 \pm 12,70$ & $4,63 \pm 1,31$ & $>0,05$ \\
\hline \multirow{2}{*}{ Интервал } & Щиколотка & $7,81 \pm 0,34$ & $7,21 \pm 0,29$ & $7,30 \pm 0,39$ & $>0,05$ \\
\cline { 2 - 6 } & Колено & $11,58 \pm 1,51$ & $10,48 \pm 1,19$ & $10,44 \pm 0,57$ & $>0,05$ \\
\hline \multirow{2}{*}{ Скорость, м/с } & Щиколотка & - & - & $44,36 \pm 2,17$ & $>0,05$ \\
\cline { 2 - 6 }
\end{tabular}

Примечание: $p$ - оценка достоверности по критерию Краскела - Уоллиса. 
Оценка функционального состояния мышц нижней конечности (F-волна n. tibialis) у пациентов с PC в зависимости от уровня спастичности

\begin{tabular}{|l|c|c|c|c|}
\hline \multirow{2}{*}{\multicolumn{1}{|c|}{ Показатель }} & \multicolumn{3}{|c|}{ Уровень спастичности } & \multirow{2}{*}{$p$} \\
\cline { 2 - 5 } & $0,4-1$ & $1,5-2$ & $6,1-3$ & $>0,05$ \\
\hline М-латентность, $M C$ & $4,4 \pm 0,52$ & $5,19 \pm 0,36$ & $8,56 \pm 0,95$ & 0,008 \\
\hline М-амплитуда, $M B$ & $3,92 \pm 0,81$ & $6,78 \pm 1,09$ & $74,62 \pm 8,82$ & $>0,05$ \\
\hline F-частота, Гц & $78,85 \pm 4,72$ & $65,53 \pm 4,80$ & $58,48 \pm 0,91$ & 0,007 \\
\hline F-латентность средняя, $M C$ & $52,93 \pm 1,15$ & $53,38 \pm 1,14$ & $476,12 \pm 119,67$ & $<0,05$ \\
\hline F-амплитуда средняя, $M B$ & $621,27 \pm 118,62$ & $487,97 \pm 79,44$ & & \\
\hline
\end{tabular}

Примечание: $p$ - оценка достоверности по критерию Краскела - Уоллиса.

Оценка функционального состояния мышц нижней конечности (Н-рефлекс) у пациентов с РС в зависимости от наличия спастичности

\begin{tabular}{|l|c|c|c|c|}
\hline \multicolumn{1}{|c|}{ Показатель } & $0,4-1$ & $1,5-2$ & $2,1-3$ & $p$ \\
\hline М-латентность, $M$ - & $9,93 \pm 2,87$ & $8,28 \pm 1,12$ & $5,93 \pm 0,16$ & $>0,05$ \\
\hline Максимум M & $3,09 \pm 1,49$ & $3,02 \pm 0,67$ & $2,68 \pm 1,01$ & $>0,05$ \\
\hline Максимум H & $0,63 \pm 0,40$ & $1,27 \pm 0,63$ & $2,5 \pm 0,11$ & $>0,05$ \\
\hline Соотношение M/H & - & $147,26 \pm 73,63$ & $44,3 \pm 0$ & $>0,05$ \\
\hline Н-латентность, $M B$ & $31 \pm 0$ & $38,2 \pm 0$ & $29,77 \pm 1,93$ & $>0,05$ \\
\hline
\end{tabular}

Примечание: $p$ - оценка достоверности по критерию Краскела - Уоллиса.

Подводя итоги нашего исследования, еще раз отметим, что у пациентов с рассеянным склерозом разного уровня спастичности было выявлено достоверное снижение амплитуды М-ответа при исследовании как верхних, так и нижних конечностей, что означает уменьшение числа мышечных волокон, участвующих в генерации М-ответа вследствие нарушения проведения аксонов. Данный показатель является наиболее чувствительным индикатором ранних проявлений спастичности. В то время как показатели поздних электрофизиологических феноменов (F-волна), прежде всего F-амплитуда средняя, меняются у больных со спастичностью только на нижних конечностях.

В результате проведенного клинико-электрофизиологического исследования больных РС получила дальнейшее развитие одна из актуальных проблем неврологии - определение индикаторов ранних признаков спастичности, которая является одним из основных инвалидизирующих фракторов больных РС. Полученные результаты имеют практическое значение в связи с тем, что ранняя диагностика спастичности при РС позволяет принять решение о своевременном назначении симптоматической терапии и задержать развитие инвалидизации.

По результатам проведенного исследования сделаны следующие выводы:

1. Результаты электронейромиографических исследований показали, что основным электрофризиологическим индикатором ранних проявлений спастичности мышц верхних и нижних конечностей у больных рассеянным склерозом является снижение амплитуды М-ответа.

2. Поздний электрофризиологический феномен F-амплитуда средняя снижается соответственно росту спастичности в нижних конечностях у пациентов с рассеянным склерозом разного уровня спастичности.
3. Показатели латентности могут как увеличиваться, так и уменьшаться у больных разного уровня спастичности.

Прозрачность исследования. Исследование не имело спонсорской поддержки. Автор несет полную ответственность за предоставление окончательной версии рукописи в печать.

Декларация о финансовых и других взачмоотношениях. Автор принимала участие в разработке концепции, дизайна исследования и в написании рукописи. Окончательная версия рукописи была одобрена автором. Автор не получала гонорар за исследование.

\section{ЛИТЕРАТУРА}

1. Завалишин, И.А. Спастический парез / И.А. Завалишин, В.П. Бархатова, И.Е. Шитикова // Рассеянный склероз. Избранные вопросы теории и практики. - Москва: Минздрав России, НИИ неврологии РАМН, 2000. C. $436-455$.

2. Spasticity: clinical perceptions, neurological realities and meaningful measurement / A.D. Pandyan, M. Gregoric, M.P. Barnes [et al.] // Disability and Rehabilitation. 2005. - Vol. 5. - P.4-14.

3. Patejdl, R. Spasticity in multiple sclerosis: Contribution of inflammation, autoimmune mediated neuronal damage and therapeutic interventions / R. Patejdl, U.K. Zettl // Autoimmun. Rev. - 2017. - Vol. 16 (9). - P.925-936.

4. Schapiro, R.T. Managing the Symptoms of Multiple Sclerosis / R.T. Schapiro. -5 th edition. - Demos Health, 2007. - 192 p.

5. Grana, E.A. Electrodiagnostic Abnormalities in Patients With Multiple Sclerosis / E.A. Grana, G.H. Kraft // Arch. Phys. Med. Rehabil. - 1994. - Vol. 75. - P.778-782.

6. Spasticity in Multiple Sclerosis / M.P. Barnes, R.M. Kent, J.K. Semlyen [et al.] // Neurorehabilitation and Natural Repair. - 2003. - Vol. 17. - P.66-67.

7. What drives quality of life in multiple sclerosis? L. Hemmett, J. Holmes, M. Barnes, N. Russell // QJM. 2004. - Vol. 97. - P.671-676.

8. Hoang, P.D. Spasticity and Multiple Sclerosis / P.D. Hoang // MS Practice (Australia). - 2009. - P.4-8. 
9. Balci, B.P. Spasticity Measurement / B.P. Balci // Noro Psikiyatr Ars. - 2018. - Vol. 55 (Suppl 1). - P.49-53.

10. What does the Ashworth scale really measure and are instrumented measures more valid and precise? / D.L. Damiano, J.M. Quinlivan, B.F. Owen [et al.] // Developmental Medicine and Child Neurology. - 2002. - Vol. 44. P.112-118.

11. Hobart, J.C. Rating scales as outcome measures for clinical trials in neurology: problems, solutions, and recommendations / J.C. Hobart, S.J. Cano, J.P. Zajicek // Lancet Neurology. - 2007. - Vol. 6 (12). - P.1094-1105.

12. Comparison of Modified Ashworth Scale and Hoffmann Reflex in Study of Spasticity / A.H. Kohan, S. Abootalebi, A. Khoshnevisan [et al.] // Acta Medica Iranica. - 2010. Vol. 48 (3). - P.154-157.

13. Pandyan, A.D. A biomechanical investigation into the validity of the modified Ashworth Scale as a measure of elbow spasticity / A.D. Pandyan, C.I.M. Price, M.P. Barnes // Clinical Rehabilitation. - 2003. - Vol. 17, № 3. - P.290-294.

14. Beer, S. Managing the Symptoms of Multiple Sclerosis, 5th edition / S. Beer // Department of Neurorehabilitation, Valens Clinic Rehabilitation Center. - 2014. - URL: https:// www.excemed.org/ms-alumni/resources/managementspasticity-multiple-sclerosis-ms

15. Drovy, V. F-wave characteristics following acute and chronic upper motor neuron lesions / V. Drovy, M.Y. Neufeld, A.D.E. Korczyn // Electromyogr Clin. Neurophysiol. 2003. - Vol. 33, Issue 7. - P.441-446.

16. Voerman, G.E. Neurophysiological methods for the assessment of spasticity:The Hoffmann reflex, the tendon reflex, and the stretch reflex / G.E. Voerman, M. Gregoric, H.J. Hermens // Disabil Rehabil. - 2005. - Vol. 27. P.33-68.

\section{REFERENCES}

1. Zavalishin IA, Barhatova VP, Shitikova IE. Spasticheskiy parez [Spastic Paresis]. V knige «Rasseyannyy skleroz; Izbrannyye voprosy teorii i praktiki»; Moskva: Minzdrav Rossii, NII nevrologii RAMN [In the book «Multiple Sclerosis; Selected questions of theory and practice»; Moscow: Russian Ministry of Health, Research Institute of Neurology, Russian Academy of Medical Sciences]. 2000; 436-455.

2. Pandyan AD, Gregoric M, Barnes MP, Wood D, Van Wijck F, Burridge J, Hermens H, Johnson GR. Spasticity: clinical perceptions, neurological realities and meaningful measurement. Disabil Rehabil. 2005; 7-21; 27(1-2): 2-6. doi: 10.1080/09638280400014576. PMID: 15799140.

3. Patejdl R, Zettl UK. Spasticity in multiple sclerosis: Contribution of inflammation, autoimmune mediated neuronal damage and therapeutic interventions. Autoimmun Rev.
2017; 16 (9): 925-936. doi: 10.1016/j.autrev.2017.07.004. Epub 2017 Jul 8. PMID: 28698092.

4. Schapiro RT. Managing symptoms of multiple sclerosis. Neurol Clin. 2005; 23 (1): 177-87. doi: 10.1016/j. ncl.2004.09.001. PMID: 15661093.

5. Grana EA, Kraft GH. Electrodiagnostic abnormalities in patients with multiple sclerosis. Arch Phys Med Rehabil. 1994; 75 (7): 778-782. PMID: 8024424.

6. Barnes MP, Kent RM, Semlyen JK, McMullen KM. Spasticity in multiple sclerosis. Neurorehabil Neural Repair. 2003; 17 (1): 66-70. doi: 10.1177/0888439002250449. PMID: 12645447.

7. Hemmett L, Holmes J, Barnes M, Russell N. What drives quality of life in multiple sclerosis? QJM. 2004; 97 (10): 671-676. doi: 10.1093/qjmed/hch105. PMID: 15367738.

8. Hoang PD. Spasticity and Multiple Sclerosis. MS Practice (Australia), June 2009. Retrieved from https://www.msaustralia.org.au/file/278/download?token=cK4rr3lc.

9. Balci BP. Spasticity Measurement. Noro Psikiyatr Ars. 2018; 55 (Suppl 1): S49-S53. doi: 10.29399/npa.23339. PMID: 30692856; PMCID: PMC6278623.

10. Damiano DL, Quinlivan JM, Owen BF, Payne P, Nelson KC, Abel MF. What does the Ashworth scale really measure and are instrumented measures more valid and precise? Dev Med Child Neurol. 2002; 44 (2): 112-118. doi: 10.1017/ s0012162201001761. PMID: 11848107.

11. Hobart JC, Cano SJ, Zajicek JP, Thompson AJ. Rating scales as outcome measures for clinical trials in neurology: problems, solutions, and recommendations. Lancet Neurol. 2007; 6 (12): 1094-1105. doi: 10.1016/S14744422(07)70290-9.

12. Kohan AH, Abootalebi S, Khoshnevisan A, Rahgozar M. Comparison of modified Ashworth scale and Hoffmann reflex in study of spasticity. Acta Med Iran. 2010; 48 (3): 154-157. PMID: 21137650.

13. Pandyan AD, Price Cl, Barnes MP, Johnson GR. A biomechanical investigation into the validity of the modified Ashworth Scale as a measure of elbow spasticity. Clin Rehabil. 2003; 17 (3): 290-293. doi: 10.1191/0269215503cr610oa. PMID: 12735536.

14. Beer S. Management of Spasticity in Multiple Sclerosis (MS). 2014; https://www.excemed.org/ms-alumni/ resources/management-spasticity-multiple-sclerosis-ms

15. Drory VE, Neufeld MY, Korczyn AD. F-wave characteristics following acute and chronic upper motor neuron lesions. Electromyogr Clin Neurophysiol. 1993; 33 (7): 441-446. PMID: 8261985.

16. Voerman GE, Gregoric M, Hermens HJ. Neurophysiological methods for the assessment of spasticity: the Hoffmann reflex, the tendon reflex, and the stretch reflex. Disabil Rehabil. 2005; 7-21; 27 (1-2): 33-68. doi: 10.1080/09638280400014600. PMID: 15799143. 